\title{
$\mathrm{Ni}_{3} \mathrm{Al}$ 金属間化合物の燃焼合成時の燃焼温度，化合物生成量 ならびに発生液相量の解析
}

\author{
日比野 敦 \\ 蔜気通信大学䉓気通信学部機械制御工学科, $\mathbf{1} 182$ 調布市調布ヶ丘1-5-1.
}

\section{Analysis of Combustion Temperature, Compound Formation Ratio and Liquid Phase Quantities in Combustion Synthesis of $\mathrm{Ni}_{3} \mathrm{Al}$ Intermetallic Compound}

\author{
Atsushi Hibino \\ Dept. of Mechanical and Control Eng., Univ. of Electro Communications, 1-5-1 Chofugaoka, Chofu 182.
}

Received June 20, 1996

\section{SYNOPSIS}

Combustion synthesis process has been taken an interest in new syuthesizing technology of intermetallic compound. However, the synthesized products tend to be porous and the process is not used practically. To realize the process, a method of synthesizing the dense product should be developed. In my previous paper, fabrication of Ni3Al intermetallic compound by pressureless combustion synthesis process was investigated. Consequently, it was found that density of the synthesized compound depended on initial powder particle sizes, and the nearly full dense product was obtained in case of using fine powders as initial substances. However, cause of the densification or mechanisms of the shrinkage have not been known. In this paper, numerical analysis of the process of NizAl was performed to clear the relationship between the densification and the compound formation stages in the combustion.

A $\mathrm{Ni} / \mathrm{Al}$ compact which burned by the thermal explosion was divided into infinite elements, a numerical analysis model of combustion synthesis was derived under consideration of heat balance and material balance equations around the elements. The model was solved by I.A.D. method, and the combustion synthesis behavior was analyzed.

The compound formation behavior during the combustion synthesis was able to be simulated. From the calculation, it is found that large quantities of liquid phases were formed in the NisAl synthesis. In the previous experiments of the combustion synthesis, the rapid shrinkage was observed during extremely short times. The quick densification might be caused by the large quantities of the liquid phases.

\section{KEY WORDS}

Combustion synthesis, SHS, Intermetallic compound, Ni3Al, Ni2 Al3, Densification, Liquid phase, Thermal analysis, Kinetics.

\section{1 緒 言}

Ni3Al，TiAlに代表される金属間化合物の製造法と して然焼合成法の適用が検討されながら未だ実用化 しないのは，多孔質体ができ緻密材が得にくいため である。この問題が解決されれば，素粉末から瞬時 にして化合物が合成でき，本来粉末治金の一種であ るので微視組織制御も可能で，本法は金属間化合物
製造の有力な手段となりうる.

こうした背景から近年，金属間化合物の燃焼合成 が多数試みられ，粉末粒径，混合比ならびに粉体 の加熱過程の制御によって次第に密度の高い化合物 が得られるようになってきた1、2)。著者も前報にお いて無加圧然烤合成によるNi3Al金属間化合物の合成 を試みた3，4，その結果，先の文献 $1 ， 2$ )を襄付ける 
結果が得られ，原料として微粉を用いれば，密度 97\%程度の緻密体が合成できることがわかった。ど うもこの繳密化は, 燃焼合成温度, 合成時の化合物 生成量ならびに発生液相量によるものと思われる。 文献5)でも合成体緻密化の鍵として温度, 液相, ガ スなどの事項が指摘されている。しかし，これまで のところ無加圧燃焼合成に上る緻密体製造例はあま りなく，かつその要因についてはほとんど知られて いない，今後の燃焼合成の展開を考えれば，燃焼合 成体緻密化の理由を検討し，緻密化の指針を確立す ることが重要と考えられる。そこで $\mathrm{Ni}_{3} \mathrm{Al}$ の燃焼合成 過程と緻密化の関連を検討することにし，本研究で はまずは数值解析から燃焼合成温度，合成時の化合 物生成量ならびに発生液相量を計算することを試み た。

\section{2 然焼合成の解析モデル}

いま, NiとAl（Ni：Al=3：1)の混合粉末からなる 圧粉体が反応し，その粉末の化学反応熱によって全 体然焼に上る燃焼合成が生じている場合を考える。 Fig.1にその解析図を示す，座標系として $(x, r)$ の円柱 座標をとり，圧粉体を図のようなりング状の微小要 素に分割する．微小要素のまわりの $x$ 方向, $r$ 方向の
熱収支を考えると，

$$
C_{\mathrm{m}}\left(\frac{\partial T}{\partial t}\right)=\lambda_{\mathrm{m}}\left\{\left(\frac{\partial^{2} T}{\partial x^{2}}\right)+\left(\frac{\partial^{2} T}{\partial r^{2}}\right)+\frac{1}{r}\left(\frac{\partial T}{\partial r}\right)\right\}+q_{\mathrm{m}}
$$

ここで,

$C_{\mathrm{m}}\left[\mathrm{J} \cdot \mathrm{m}^{-3} \cdot \mathrm{K}^{-1}\right]$ : 圧粉体単位体積の熱容量,

$\lambda_{\mathrm{m}}\left[\mathrm{W} \cdot \mathrm{m}^{-1} \cdot \mathrm{K}^{-1}\right]$ : 圧粉体の熱伝導率,

$q_{\mathrm{m}}\left[\mathrm{W} \cdot \mathrm{m}^{-3}\right]$ : 圧粉体の単位体積の発熱速度.

一方，燃焼合成では著しい温度変化があるため， 压粉体の融解や変態など相転移の現象が生じる可能 性がある．解析のうえではこの相転移に伴う吸発熱 も考慮する必要がある。．その解析図をFig.2に示す。 圧粉体内の位置 $\left(x_{\mathrm{f}}, r_{\mathrm{f}}\right)$ の微小要素が相転移温度に達 $し て$, 時間 $\mathrm{d} r$ の間にこの微小要素体積 $2 \pi r d r d の う$ ち割合 $2 \pi r d r d r d$ が相転移したとする。 この微小要 素の熱収支から，圧粉体の相転移に関して，

$$
\begin{aligned}
q_{\mathrm{f}}\left(\frac{\mathrm{d} f}{\mathrm{~d} t}\right) & =\lambda_{\mathrm{m}}\left\{\frac{1}{\mathrm{~d} x}\left[\frac{\partial T}{\partial x}\right]_{x=x_{\mathrm{f}}+\mathrm{d} x}-\frac{1}{\mathrm{~d} x}\left[\frac{\partial T}{\partial x}\right]_{x=x_{\mathrm{f}}}\right\} \\
& +\lambda_{\mathrm{m}}\left\{\left(1+\frac{\mathrm{d} r}{r}\right) \frac{1}{\mathrm{~d} d}\left[\frac{\partial T}{\partial r}\right]_{r=r_{\mathrm{f}}+\mathrm{d} r}-\frac{1}{\mathrm{~d}}\left[\frac{\partial T}{\partial r}\right]_{r=r_{\mathrm{f}}} \mid+q_{\mathrm{m}}\right.
\end{aligned}
$$

ここで,

$f[-1:$ 压粉体微小要素内の相転移率, $a_{\mathrm{f}}\left[\mathrm{J} \cdot \mathrm{m}^{-3} \mathrm{l}\right.$ : 圧粉体単位体積の相転移の潜熱.

本研究では上記式(1)，(2)に基づき，解析を進めた.

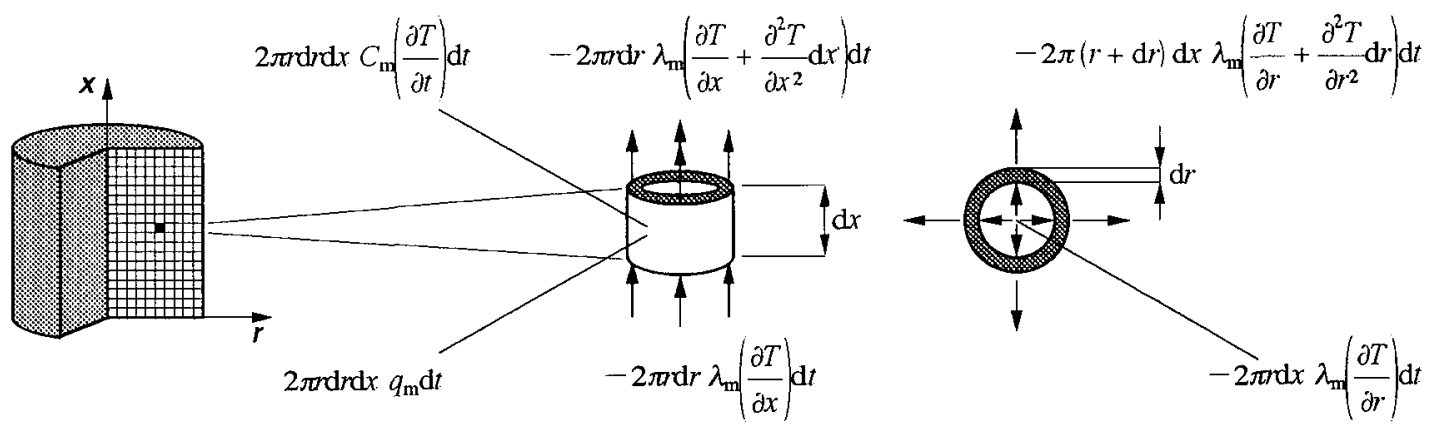

Fig. 1: Numerical model for analysis of combustion synthesis process. (Thermal explosion combustion synthesis.)

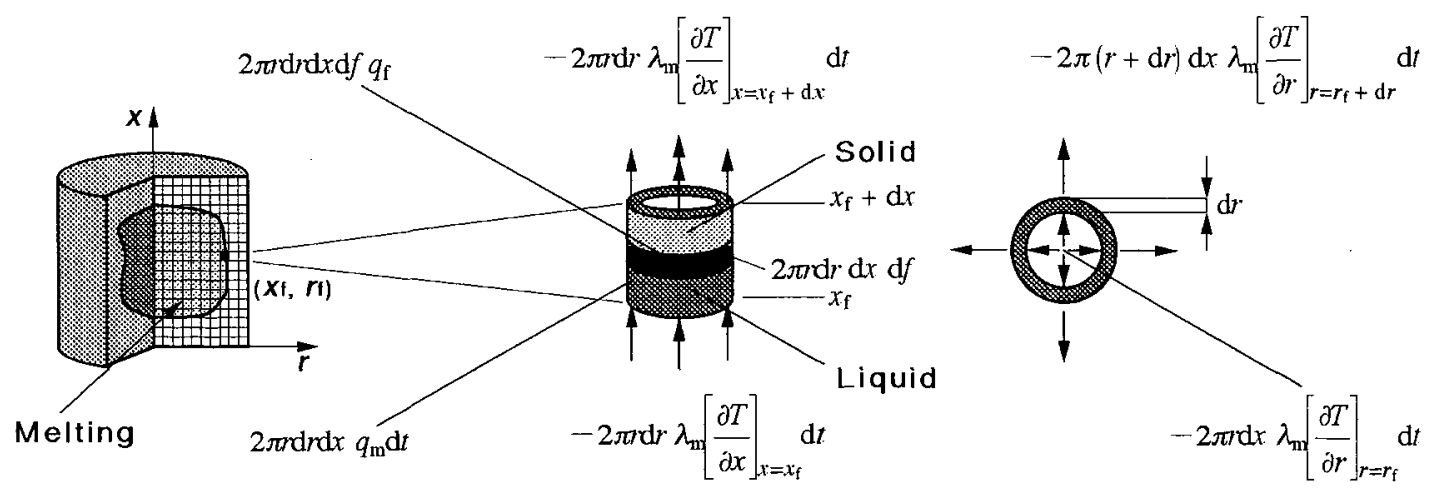

Fig.2: Numerical model of phase transformation in combustion synthesis process. 


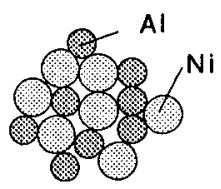

(a) Ni/Al premixed compáct.

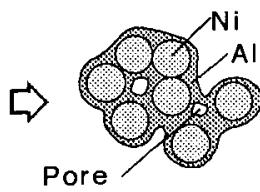

(b) Melting of Al particle.

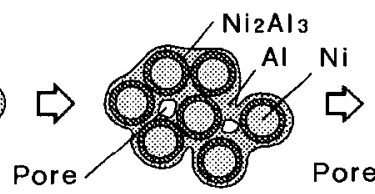

(c) Combustion synthesis.

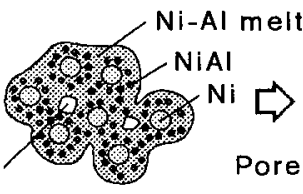

(d) Combustion synthesis.

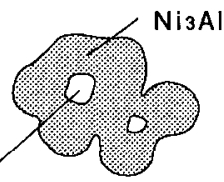

(e) Synthesized product.

Fig.3: Schematic drawing of microstructural changes from $\mathrm{Ni}$ and $\mathrm{Al}$ elemental powders to Ni3Al intermetallic compound.

\section{3 圧粉体モデル}

解析の圧粉体は,これまでの燃焼合成の組織観察 結果に基づいて設定した，Fig.3は以前，著者が実験 的に調べた Ni3 $\mathrm{Al}$ の燃焼合成過程を示した図である6). 本系の燃焼合成では，Ni/Al混合圧粉体を加熱すると まず $\mathrm{Al}$ の粒子が融解し，Ni粒子の周囲に浸透する

(Fig.3(b)）。次いでこのA1融液と Ni粒子との反応で $\mathrm{Ni} 2 \mathrm{Al} 13$ が生成し，この反応熱で圧粉体の温度が上昇 する（Fig. 3(c)）。その後 $\mathrm{Ni}_{2} \mathrm{Al}_{3}$ は $\mathrm{NiAl}$ と $\mathrm{Ni}-\mathrm{Al}$ 融液 へと分解し(Fig.3(d)），Ni3Alが合成されると推測さ れる(Fig.3(e))。

そこでFig.4のような球殼粒子を考え，この粒子に よって燃焼合成が生じると考えた。すなわちA1融液 を $\mathrm{Ni}$ とAlの混合比率 $(\mathrm{Ni}: \mathrm{Al}=3: 1)$ に従って $\mathrm{Ni}$ 粒 子1個あたりに配分する。そとしてこの粒子外側のA1融 液と中心部の $\mathrm{Ni}$ との間で $\mathrm{Ni}_{2} \mathrm{Al}_{3}$ の生成反応が生じ, 燃焼合成が生じるものと考えた。また，圧粉体は Fig.5のように粒子の集合体として考えた. $\mathrm{Ni}-\mathrm{Al}$ 系

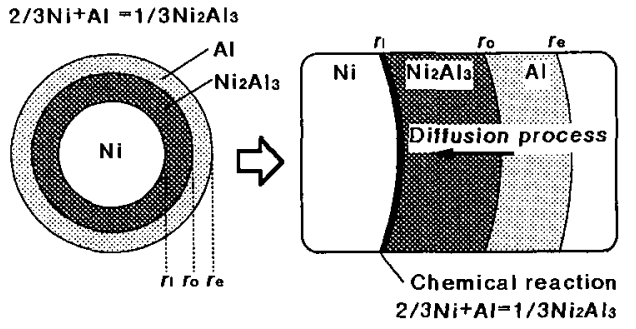

Fig.4: Reaction model between Ni powder particle and Al melt. (Spherical shell model)
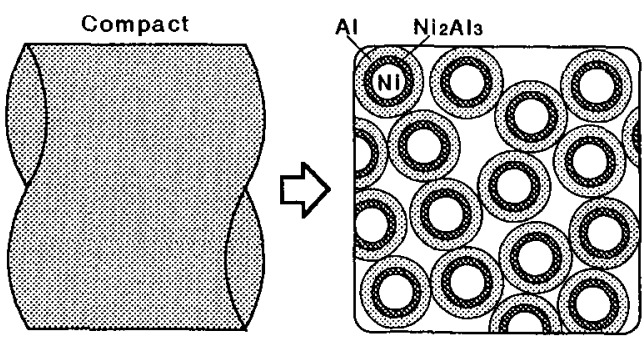

Fig.5: Compact model for analyzing of combustion synthesis of Ni3Al intermetallic compound.
状態図7)によれば，Ni2Al3は1406KでNiAlと Ni-Al瀜 液へと分解する。このため，この温度以上では $\mathrm{Ni} 2 \mathrm{Al}_{3}$ 以外の化合物が生成する可能性がある。一方， 本燃焼合成の最終化合物はNi3Alであるので，この生 成も考虑する必要がある。しかしこれまでの実測6) では，本系の燃焼合成時間の大半をFig.3(c)が占める. そこで，まずはFig.4，5の圧粉体で本反応を近似さ せることにした。

\section{4 連続体から粒子集合体への換 算}

以上の解析のためには，連続体の式(1)，(2)を粒子 集合体である圧粉体へと換算する必要がある，これ らはFig.4，5から導出した．Fig.5のように圧粉体に 粒子が無数に充填されているものとする。圧粉体の 粉末充填率を $\rho$ とし，粒子 1 個の体積をVとすれば, 熱容量 $C_{\mathrm{m}}$ ，発热速度 $q_{\mathrm{m}}$ は粒子一個あたりの值を用 いて表せば,

$$
\begin{aligned}
& C_{\mathrm{m}}=\left(\bar{C}_{\mathrm{p}} / V\right) \rho \\
& q_{\mathrm{m}}=(q / V) \rho
\end{aligned}
$$

ここで,

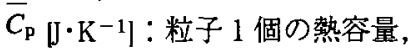

$V\left[\mathrm{~m}^{3}\right]:$ 粒子 1 個の体積,

$\rho_{[-]}$: 圧粉体の粉末充填率,

$q[\mathrm{~W}]$ : 粒子 1 個の発熟速度.

圧粉体の熱伝導率 $\lambda_{\mathrm{m}}$ \&，圧粉体の粉末充填率 $\rho に$ 対して比例関保が成立すると仮定すれば，

$$
\lambda_{\mathrm{m}}=\lambda_{\text {Ni-Al }} \cdot \rho
$$

従って, 式(3)（5)を式(1)に代入して,

$\frac{\bar{C}_{\mathrm{p}}}{V}\left(\frac{\partial T}{\partial t}\right) \rho=\lambda_{\mathrm{Ni}-\mathrm{Al}} \cdot \rho\left\{\left(\frac{\partial^{2} T}{\partial x^{2}}\right)+\left(\frac{\partial^{2} T}{\partial r^{2}}\right)+\frac{1}{r}\left(\frac{\partial T}{\partial r}\right)\right\}+\frac{q}{V} \cdot \rho$

一方，燃焼合成における压粉体の相転移の潜熱 $a$ も，粒子1個の相転移の熱量を市とすると，

$$
q=\left(\bar{q}_{\mathrm{p}} / V\right) \rho \quad(7)
$$

さらに，粒子 1 個の内部で相転移する物質のモル数を $n \boldsymbol{r} ， そ の$ 物質の相転移の潜熱を $\Delta H_{\mathrm{f}}$ とすれば,

$$
q_{\mathrm{f}}=\left(\bar{q}_{\mathrm{p}} / V\right) \rho=\frac{n_{\mathrm{f}} \Delta H_{\mathrm{f}}}{V} \rho
$$

従って，粒子1個の相転移の熱収支式は， 
$\frac{n+\Delta H_{\mathrm{f}}}{V}\left(\frac{d f}{d z}\right) \cdot \rho=\lambda_{\mathrm{Ni}-\mathrm{A} I} \cdot \rho\left\{\frac{1}{d x}\left[\frac{\partial T}{\partial x}\right]_{x=x_{\mathrm{f}}+\mathrm{dx}}-\frac{1}{\mathrm{~d} x}\left[\frac{\partial T}{\partial x}\right]_{x=x_{\mathrm{f}}}\right\}$

$+\lambda_{\mathrm{Ni}-\mathrm{Al}} \cdot \rho\left\{\left(1+\frac{d r}{r}\right) \frac{1}{d}\left[\frac{\partial T}{\partial r}\right]_{r=r_{\mathrm{f}}+\mathrm{d} r}-\frac{1}{d}\left[\frac{\partial T}{\partial r}\right]_{r=r_{\mathrm{f}}}\right\}+\frac{q}{V} \cdot \rho$

ここで,

$\lambda_{\mathrm{Ni}-\mathrm{Al}}\left[\mathrm{W} \cdot \mathrm{m}^{-1} \cdot \mathrm{K}^{-1}\right] ：$ 化合物の熱伝導率,

$\mathrm{a}\left[\mathrm{J} \cdot \mathrm{m}^{-3}\right]$ : 圧粉体単位体積あたりの相転移の潜熱,

$q_{\mathrm{q}}[\mathrm{J}]$ : 粒子 1 個の相転移の潜熱，

$n_{\mathrm{f}}[\mathrm{moll}]$ : 粒子 1 個で相転移する物質のモル数,

$\Delta H_{\mathrm{f}}\left[\mathrm{J} \cdot \mathrm{mol}^{-1}\right]$ : 相転移する物質の融解潜熱.

なお，この相転移はここではFig.6に従うとして考 えた.つまりは, 1658Kで (Ni3A1の融点)ではNi2Al3 が融解するとして扱った。

\section{5 压枌体の物性值}

式の各物性值は、これまでに著者が導出した式を 用いた8).Fig.4の粒子のNiとAlの反応を式で示せば,

$$
\begin{aligned}
k_{\mathrm{c}} & \rightarrow \\
2 / 3 \mathrm{Ni}+ & \mathrm{Al}=1 / 3 \mathrm{Ni}_{2} \mathrm{Al}_{3} \quad \Delta H^{\circ}, K=\frac{k_{c}}{k_{\mathrm{b}}} \\
\leftarrow & \leftarrow k_{\mathrm{b}}
\end{aligned}
$$

この反応が以下の3段階で進行すると考えれば，

(1)外周の $\mathrm{Al}$ は $\mathrm{Ni}_{2} \mathrm{Al}_{3}$ 層を拡散して $\mathrm{Ni}_{2} \mathrm{Al}_{3} / \mathrm{Ni}$ 界面へと

移動する。

(2)その層を通過したAlが Niと反応して $\mathrm{Ni}_{2} \mathrm{Al} 3$ 層を成

長させる。

(3) $\mathrm{Ni}_{2} \mathrm{Al}_{3}$ が生成した結果，反応熱が発生する。 粒子の発熱速度 $q$ は,

$$
\begin{aligned}
& q=2 \pi r_{\mathrm{s}}^{3} \frac{\rho_{\mathrm{Ni}}}{M_{\mathrm{Ni}}} \frac{\mathrm{d} C}{\mathrm{~d} t} \Delta H^{0} \\
& =\frac{4 \pi r_{\mathrm{s}}^{2} \beta^{2 / 3}(1-1 / K)}{\frac{\beta^{1 / 3} r_{\mathrm{s}}}{\alpha^{1 / 3} D_{\mathrm{Al}}}\left(\beta^{1 / 3}-\alpha^{1 / 3}\right)+\frac{\beta^{2 / 3}}{\alpha^{2 / 3} k_{\mathrm{c}}}} \Delta H^{\circ} \\
& \alpha=1-C, \beta=\left(\frac{\rho_{\mathrm{Ni}} M_{\mathrm{Ni}_{2} \mathrm{Al} 3}}{2 M_{\mathrm{Ni}} \rho_{\mathrm{Ni}_{2} \mathrm{Al}}}-1\right) C+1
\end{aligned}
$$

粒子の熱容量 $\bar{C}_{\mathrm{p}}$ は,

$$
\begin{aligned}
& \bar{C} \mathrm{p}=2 \pi r_{\mathrm{s}}^{3} \frac{\mathrm{PNi}_{\mathrm{Ni}}}{M_{\mathrm{Ni}}} \\
& \times\left\{\frac{2}{3}(1-C) C \mathrm{PNi}+\frac{1}{3} C \cdot C \mathrm{PNi}_{2} \mathrm{Al}_{3}+\left(\frac{2}{9}-C\right) C \mathrm{p}_{\mathrm{Al}}\right\}
\end{aligned}
$$

粒子の体積 $V$ は,

$$
\begin{aligned}
& V=\frac{4_{3}}{3} r_{\mathrm{s}}^{3} \\
& \times\left[\left\{\left(\frac{\rho_{\mathrm{Ni}} M_{\mathrm{Ni}_{2} \mathrm{~A}_{3}}}{2 M_{\mathrm{Ni}} \rho_{\mathrm{Ni}_{2} \mathrm{Al}_{3}}}-1\right) C+1\right\}+\frac{3 \rho_{\mathrm{Ni}} M_{\mathrm{Al}}}{M_{\mathrm{Ni}} \rho_{\mathrm{Al}}}\left(\frac{1}{9}-\frac{1}{2} C\right)\right]
\end{aligned}
$$

粒子内のAl, $\mathrm{Ni}_{2} \mathrm{Al} 3, \mathrm{Ni}$ のモル数 $n_{\mathrm{Al}}, n_{\mathrm{Ni} 2 \mathrm{Al}}, n_{\mathrm{Ni}}$ は,

$$
n_{\mathrm{Al}}=2 \pi r_{\mathrm{s}}^{3}\left(\frac{2}{9}-C\right) \frac{\rho_{\mathrm{Ni}}}{M_{\mathrm{Ni}}}
$$

$$
\begin{aligned}
& n_{\mathrm{Ni}_{2} \mathrm{Al}_{3}}=\frac{2}{3} \pi r_{8}^{3} C \frac{\rho_{\mathrm{Ni}}}{M_{\mathrm{Ni}}} \\
& n_{\mathrm{Ni}}=\frac{4}{3} \pi r_{\mathrm{s}}^{3}(1-C) \frac{\rho_{\mathrm{Ni}}}{M_{\mathrm{Ni}}}
\end{aligned}
$$

なおC は，次式で定義される粒子の化合物への転 換率であり，

$$
C=\frac{r_{\mathrm{s}}^{3}-r_{i}^{3}}{r_{\mathrm{s}}^{3}}=\frac{\text { 消費された } \mathrm{Ni} \text { の体積 }}{\text { 反応前の } \mathrm{Ni} \text { の体積 }}
$$

また，

$n_{1}[\mathrm{~m}] ： \mathrm{Fig} .4$ の $\mathrm{Ni}_{2} \mathrm{Al}_{3} / \mathrm{Ni}$ 界面の半径,

$r_{\mathrm{s}}[\mathrm{m}]$ : 反応前の $\mathrm{Ni} の$ 半径,

$\Delta H^{\mathrm{o}} \mathrm{J} \cdot \mathrm{mol}^{-1} \mathrm{]}:$ 式(10)のエンタルビー変化,

$K[-]:$ 式 $(10)$ の平衡定数,

$\rho_{\mathrm{Ni}}, \rho_{\mathrm{Ni} 2 \mathrm{Al} \text {, }}, \rho_{\mathrm{Al}}\left[\mathrm{kg} \cdot \mathrm{m}^{-3} \mid\right.$ : 各物質の密度,

$\boldsymbol{M}_{\mathrm{Ni}}, \boldsymbol{M}_{\mathrm{Ni} 2 \mathrm{Al}}, \boldsymbol{M}_{\mathrm{Al}}\left[\mathrm{kg} \cdot \mathrm{mol}^{-1}\right]$ : 各物質のモル量,

$C \mathrm{p}_{\mathrm{Ni}}, C \mathrm{p}_{\mathrm{Ni}_{2} \mathrm{Al}}, C \mathrm{p}_{\mathrm{Al}}\left[\mathrm{J} \cdot \mathrm{mol}^{-1} \cdot \mathrm{K}^{-1}\right]$

\section{: 各物質のモル比熱.}

$D_{\mathrm{Al}}\left[\mathrm{mol} \cdot \mathrm{m}^{-1} \cdot \mathrm{s}^{-1}\right]: \mathrm{Ni}_{2} \mathrm{Al}_{3}$ 層のAlの拡散係数,

$k_{\mathrm{f}}\left[\mathrm{mol} \cdot \mathrm{m}^{-2} \cdot \mathrm{s}^{-1}\right]$ : 式(12)の反応速度定数.

一方，相転移については，Fig.6に従って進行する ものとして，粒子の相転移するモル数婂および潜熱 $\Delta H_{\mathrm{f}}$ は, $\mathrm{Ni}_{2} \mathrm{Al}{ }_{3}$ の数とその潜熱加ら，

$\mathrm{Ni}_{2} \mathrm{Al}_{3}$ 層の融解点 $(1658 \mathrm{~K}=\mathrm{Ni3} \mathrm{Al}$ の融点 $)$ で,

$\Delta H_{\mathrm{f}}=\mathrm{Ni}_{2} \mathrm{Al}_{3}$ の融解の潜熱 $\quad n_{\mathrm{f}}=n_{\mathrm{Ni}, A l_{3}}$

\section{6 初期条件と境界条件}

初期条件と境界条件は，実際の燃焼合成を想定し て設定した．Fig.7に，初期条件と境界条件の概略を 示す，本系の燃焼合成の自己着火温度を測定すると， およそ $\mathrm{Ni}-\mathrm{Al}$ 系の共晶温度(913K)付近から燃焼合成 が開始した6)。これは融液の生成浸透で $\mathrm{Ni}$ と $\mathrm{Al}$ の接触

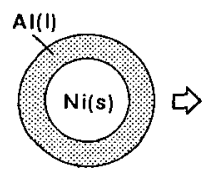

(a) $T=913 \mathrm{~K}$

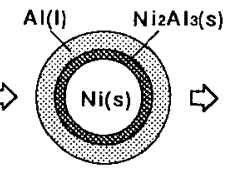

(b) $913<T<1658 \mathrm{~K}$

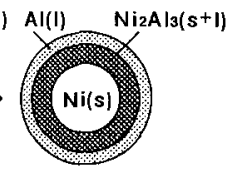

(c) $T=1658 \mathrm{~K}$
Fig6: Phase transformation model.

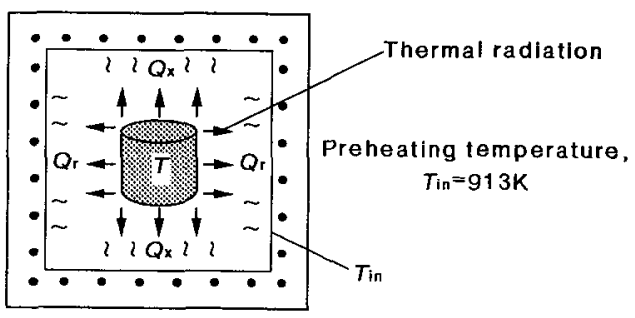

Electric furnace

Fig.7: Initial condition and boundary condition for numerical calculation. 
面積が増えること，また粉末表面の薄い酸化皮膜が 破れ易くなり反応が容易になること，さらには粉末 間の反応熱が潜熱へと吸収されず，温度上昇に費や されるようになるためと推測される。微粉では接触 面積が大幅に增えるため，より低温側からも燃狫合 成が開始するようである。しかし，本解析では一つ の指標として $T_{\text {in }}=913 \mathrm{~K} に \mathrm{Ni} / \mathrm{Al}$ 混合圧粉体が予熱さ れ，全体燃焼での燃焼合成が生じたとの初期条件を

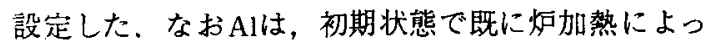
て融解しているものと扱った。

また境界条件は，輻射による熱損失を設定した。 燃焼合成時の圧粉体は粉末の反応によって著しい高 温に加熱される。しかし，炉壁は予熱温度そのまま であるため，圧粉体との間には大きな温度差が生じ る、温度差が生じれば輻射が生じ，熱は逃げること になる。そこで，次式の輻射伝熱式を境界条件とし た。

$$
\begin{aligned}
& Q_{x}=\rho \frac{d\left(T^{4}-T_{\text {in }}^{4}\right)}{\frac{1}{\varepsilon_{1}}+\frac{1}{\varepsilon_{2}}-1}=\rho \sigma\left(T^{4}-T_{\text {in }}^{4}\right) \\
& Q_{\mathrm{r}}=\rho \frac{\left.d T^{4}-T_{\text {in }}^{4}\right)}{\frac{1}{\varepsilon_{1}}+\frac{A_{1}}{A_{2}}\left(\frac{1}{\varepsilon_{2}}-1\right)}=\rho \sigma\left(T^{4}-T_{\text {in }}^{4}\right)
\end{aligned}
$$

ここで,

$Q_{\mathrm{x}}, Q_{\mathrm{r}}\left[\mathrm{W} \cdot \mathrm{m}^{-2}\right]:$ 圧粉体表面加の $\mathrm{x}$ 方向, $r$ 方向の輻射熱流束,

$T[\mathrm{~K}]$ ：燃焼合成時の圧粉体表面温度,

$T_{\text {in }}[\mathrm{K}]$ ：圧粉体の予熱温度（二炣壁温度），

$A_{1}, A_{2}\left|\mathrm{~m}^{2}\right|$ : 压粉体表面積, 電気炬内面積,

$\varepsilon_{1}=1 ， \varepsilon_{2}=1[-]$ : 圧粉体の放射率, 炉壁の放射率, $\sigma\left[\mathrm{W} \cdot \mathrm{m}^{-2} \cdot \mathrm{K}^{-4}\right]:$ ステファンボルッマン定数.

なお，压粉体ならびに炉壁の放射率は，ワーストケ 一スを想定し輻射が最大となる $\varepsilon_{1}=1 ， \varepsilon_{2}=1$ を与えた. 計算は，以上の式をI.A.D法で差分化して行った。 そして, この数值解加圧粉体の燃焼温度, 化合物

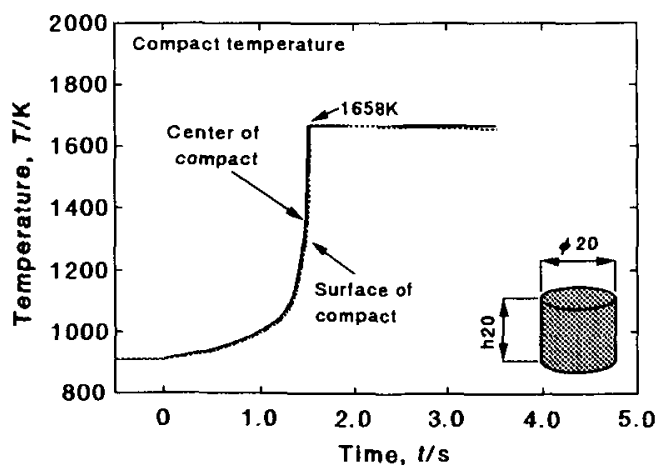

Fig.8: Calculated val ue of compact temperature during combustion synthesis.
生成量ならびに発生液相量を計算し，本系の綇密化 について検討することにした，なお，計算に必要な 物性値は文献帛方ら引用し，また $D_{\mathrm{Al}} ， k_{\mathrm{c}}$ の反応速度 定数は，浸漬実験による実測值を使用した ${ }^{10)}$.

$$
\begin{aligned}
& D_{\mathrm{Al}} / \mathrm{mol} \cdot \mathrm{m}^{-1} \cdot \mathrm{s}^{-1}=1.20 \times 10^{-3} \exp (-89000 / R T) \\
& k_{\mathrm{c}} / \mathrm{mol} \cdot \mathrm{m}^{-2} \cdot \mathrm{s}^{-1}=1.35 \times 10^{4} \exp (-120000 / R T)
\end{aligned}
$$

\section{7 燃焼合成温度、化合物生成量，} 発生洨相量の解析

Fig.8に，以上の解析から得られたNi3AIの燃焼合成 の解析結果を示す.今回の解析での原料粉末は $4 \mu$ $\mathrm{mNi}+\mathrm{Al}$ である．また圧粉体直径は $20 \mathrm{~mm}$ ，高さは $20 \mathrm{~mm}$ ，粉末充填率は $\rho=50 \%$ とした。なお，Alは初 期状態で融夜としたため，その粒径は考慮しなかっ た．解析の結果, 圧粉体の温度が上昇し, 燃焼合成 の進行を計算させることができた。この結果では， 燃焼最高温度は $1658 \mathrm{~K}$ となっている。これをFig.9の 温度一エンタルピー線図から求まる断熱燃焼温度と 比較するとよく一致することがわかる，原理的に考 えれば，輻射熱損失がある場合，最高燃焼温度は断 熱燃焼温度より下がるはずである。しかしこのよ うに両者に一致が見られたのは，最高燃焼温度が Ni3Alの融点で押さえられるためと思われる。

一方，Fig.10には，化合物への転換率を計算させ た結果を示す。化合物への転換率も時間と共に上昇 し，燃焼合成に伴う化合物合成を計算させることが できた。なお，ここでの化合物への転換率は $\mathrm{Ni}_{2} \mathrm{Al}_{3}$ の生成を仮定したため，最大 $r=2 / 9$ となる.

$\mathrm{Ni}+1 / 3 \mathrm{Al}=1 / 9 \mathrm{Ni}_{2} \mathrm{Al}_{3}+7 / 9 \mathrm{Ni}$

Fig.11には，この燃焼合成時の圧粉体温度分布，

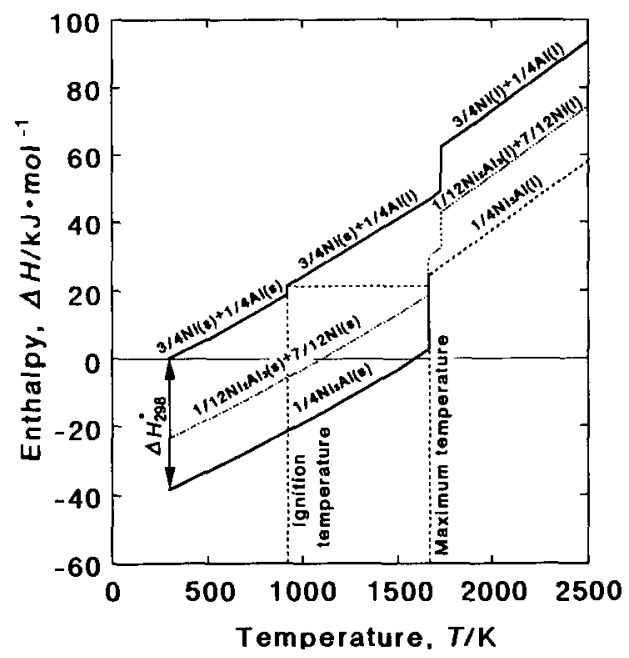

Fig.9: Enthalpy of $\mathrm{Ni3Al}, \mathrm{Ni} 2 \mathrm{Al} 3+\mathrm{Ni}$ and $3 \mathrm{Ni}+\mathrm{Al}$. 
ならびに化合物分布を示す。なおこれらの值は，圧 粉体中心軸 $x$ 方向の分布である. 圧粉体の表面部分 ではやや燃焼温度は低くなり，また化合物への転換 率も低くなった。しかし，中心部と周辺との差はほ とんどなく，ほほ均一に化合物が合成されている。

また $r$ 方向に同様に調べた結果も，中心と表面との美 はあまりなく，化合物は圧粉体内での位置によらず， ほ浔同一に合成されることがわかった。そこで以下 では圧粉体中心の値を代表值として扱うことにする.

式(14)〜(16)を用いれば，合成時の粒子のNi，Al, $\mathrm{Ni}_{2} \mathrm{Al}_{3}$ のモル数の推移が計算される。Fig.12に，粒子 内部の $\mathrm{Al}, \mathrm{Ni} 2 \mathrm{~A} 1_{3}, \mathrm{Ni}$ 各層の推移を示す. 然焼合成 の准行に伴ってNi, Alは隇少し, 代わってNiz $\mathrm{Al}_{3} か ゙$ 生成する様子がわかる。この值に基づいて然焼合成 時の粒子の様子をシミュレートしたところ，Fig.13 の上うな化合物の成長挙動が再現できた.

Fig.3からすると，本系で可能性ある発生融液は， $\mathrm{Al}$ 融解に伴う $\mathrm{Al}$ 融液, $\mathrm{Ni}_{2} \mathrm{Al}_{3}$ 分解による $\mathrm{Ni}-\mathrm{Al}$ 融液 ならびに，最高燃焼温度時の $\mathrm{Ni}_{3} \mathrm{~A} 1$ の融解融液である。 これらは以下のようにして計算した，Al融液は，燃 焼合成開始直後に生成し, 次第に化合物へと反応す る。量的には反応開始直後が最も多く，次第に量は 減少する. そこで, 代表值として燃焼合成開始温度 $913 \mathrm{~K}$ での液相量をここでは計算させた。 また NiーAl 融液は, $\mathrm{Ni}_{2} \mathrm{Al}_{3}$ の分解によって生じると考えられる. $\mathrm{Ni}-\mathrm{Al}$ 系状態図7)ではNi2 $\mathrm{Al} 3$ の分解温度は $1406 \mathrm{~K}$ とさ れている。そこで1406Kに扔けるNi2 $\mathrm{Al}_{3}$ 生成量に, $\mathrm{NiAl}$ と $\mathrm{Ni}-\mathrm{Al}$ 融液の分解比率を乗し，さらに現存す るAl融液を加算して，この液相量を計算させた，一 方, $\mathrm{Ni}_{3} \mathrm{Al}$ の融解に伴う液相量は, 本解析では $\mathrm{Ni} 2 \mathrm{Al} 3$ 生成を仮定したため, 直接その融解量は求められな かった。しかしFig.9の温度エエンタルピー線図から， エネルギー的に等価な点を求めれば， $\mathrm{Ni} 3 \mathrm{~A} 1$ の液相量 が推測される.つまりは。

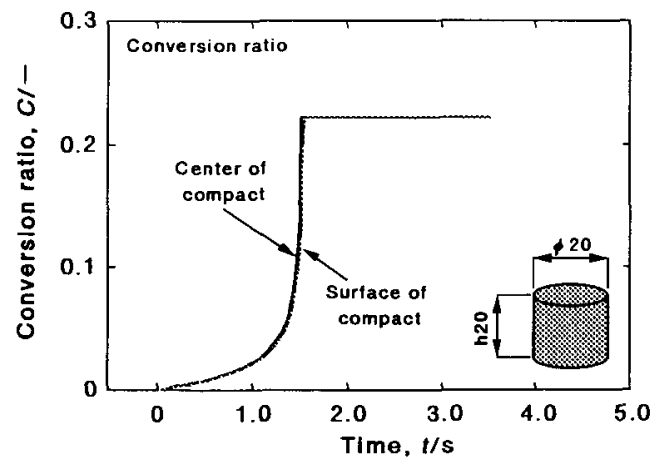

Fig. 10: Calculated $v$ al ue of conversion ratio during combustion synthesis.
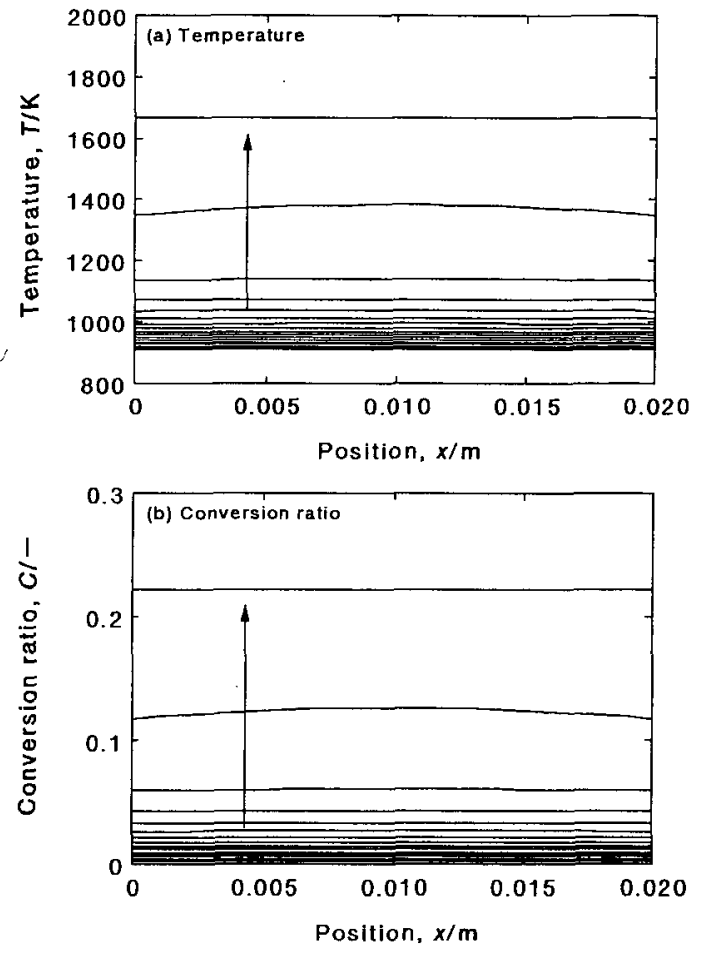

Fig.11: Distributions of temperature and conversion ratio in com pact.

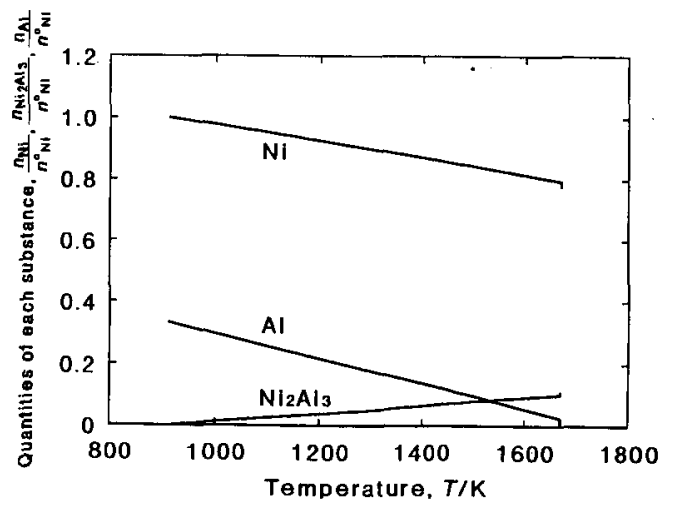

Fig.12: Change of each subs tance quantities with progress of combustion synthesis.

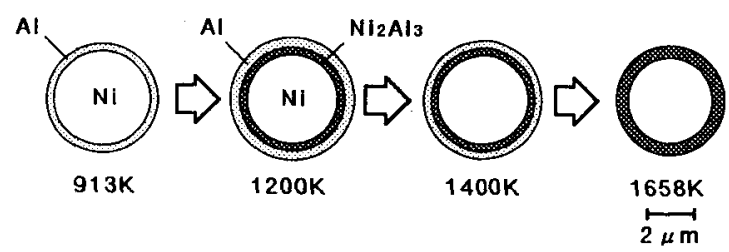

Fig. 13: Schematic drawing of compound grow th behavi or during combustion synthesis. 


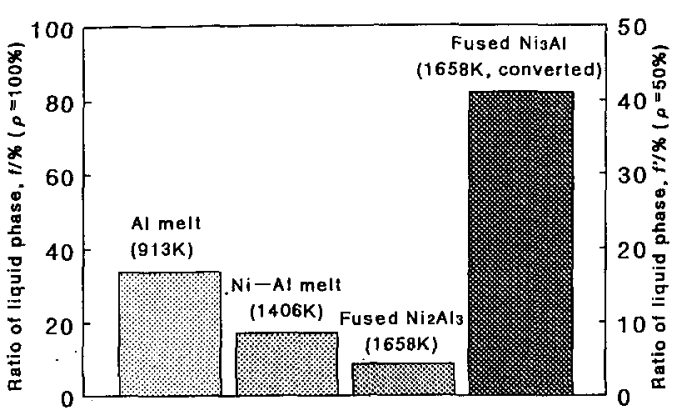

Fig. 14: Ratio of liquid phase during combustion synthesis process.

$\left(\mathrm{Ni}(\mathrm{s})+\mathrm{Ni} 2 \mathrm{Al}_{3}(\mathrm{~s})+\mathrm{Ni}_{2} \mathrm{Al}_{3}(\mathrm{l})\right)$ のエンタルピー $=(\mathrm{Ni} 3 \mathrm{Al}(\mathrm{s})+\mathrm{Ni} 3 \mathrm{Al}(1))$ のエンタルピー

としてその液相量を推測した.ただし1406～1658K の区間は低温側の外挿となるため, $\mathrm{Ni}_{2} \mathrm{Al}_{3}$ の物性值 と $\mathrm{NiAl}+(\mathrm{Ni}-\mathrm{Al}$ 融液 $)$ の物性值が近似的に等しいと考 えた場合の推測值である。その計算値を Fig. 14 に示 す、いずれも液相率としては非常に高い值を示すこ とがわかった。中でもNi3A10融解に伴う液相率は非 常に高く，約 $83 \%$ を示した. 次いでA1融液, $\mathrm{Ni}_{2} \mathrm{Al}_{3}$ の包晶分解に伴う $\mathrm{Ni}-\mathrm{A} 1$ 融䓜の順であることがわか った。しかし，この值は粒子1個あたりの液相率であ るため，圧粉体の気孔率は $0 \%$ 換算となる。例えば相 対密度 $50 \%$ の圧粉体としても, 液相量はFig. 14 の半 分となり（本図右縦軸），本然焼合成では多量の融 液が生成する可能性のあることがわかった。これら 融液のどれが緶密化に寄与するかは，こうした計算 だけからでは難しい。しかし，然焼合成という秒単 位の短い時間に維密化を生しささるには，粒子の再 配列を促進する意味でも，この程度の融液は必要と 思われる。

これまで然焼合成については現象面では知られな がらも，その合成過程は良く知られないままとされ てきた．また，実験的にその内容をとらえようとす る試みも行われてはいたが, 定量的な議論までは至 っていなかった. しかし, 今回の解析では多くの仮
定を含むものの，こうした解析的手法をさらに押し 進めてゅけば，ある程度燃焼合成の内部を推測する ことができる．今後，解析だけでなく実験がらも然 焼合成を検討し，緻密化の指針を確立することが重 要となる。

\section{8 結 言}

本研究では， Ni3A1然焼合成の微視組織変化に基づき その解析モデルを作成した。そして，このモデルを 用いて燃焼合成過程を検討した。その結果，燃焼合 成温度, 化合物生成量ならびに発生液相量が解析で き，本系の燃焼合成では多量の液相が生成する可能 性のあることがわかった。これまで然焼合成の過程 は未知のままとされ，またその内容を定量的に議論 することも難しかった. しかし、こうした解析的手 法を進めてゆけば，ある程度の推測が可能となる。 今後，解析だけでなく実験的にも燃焼合成を検討し， 䎦密化の指針を確立することが，本法発展にとって 重要となる。

\section{文 献}

1) A. Bose, B. H. Rabin, R. M. German: Powder Met. Int., 20(1988), 25.

2) K. A. Philpot, Z. A. Munir, J. B. Holt: J. Mater. Sci., 22(1987), 159 .

3) 日比野敦：粉体および粉末冶金，42(1995), 1264.

4) 日比野敦，木内學：粉体抢よび粉末治金, 42(1995), 1270.

5) Z. A. Munir: Ceram. Bull., 67(1988), 342.

6) 日比野敦：日本金属学会誌，56(1992)，1435.

7) T. B. Massalski, J. L. Murry (Ed.): "Binally Alloy Phase Diagrams", American Society for Metals, Ohio, (1986).

8) 日比野敦：日本金属学会誌，56(1995)， 717 .

9) I. Barin: "Thermochemical Data of Pure Substances", VCH, Weinheim, (1989).

10) 日比野敦：日本金属学会誌，57(1993)，767. 